Received Date : 03-Jul-2016

Revised Date : 13-Sep-2016

Accepted Date : 24-Sep-2016

Article type : Systematic review

\title{
When love hurts. A systematic review on the effects of endometriosis surgical and pharmacological treatments on female sexual functioning
}

Running headline: Endometriosis and sexual functioning

Giussy BARBARA ${ }^{1}$, Federica FACCHIN ${ }^{2}$, Michele MESCHIA ${ }^{3}$, Nicola BERLANDA ${ }^{1}$, Maria Pina FRATTARUOLO ${ }^{4} \&$ Paolo VERCELLINI $^{4}$

${ }^{1}$ Department of Obstetrics and Gynecology, Fondazione IRCCS Ca' Granda, Ospedale Maggiore Polyclinic Hospital, Milan, ${ }^{2}$ Faculty of Psychology, Catholic University of Milan, Milan, ${ }^{3}$ Department of Obstetrics and Gynecology, “G. Fornaroli” Hospital, Milan, ${ }^{4}$ Department of Women's and Children's Health, Fondazione IRCCS Ca' Granda, Ospedale Maggiore Polyclinic Hospital and University of Milan, Milan, Italy

\section{Corresponding author:}

Giussy Barbara

Department of Obstetrics and Gynecology, Fondazione IRCCS Ca' Granda, Ospedale Maggiore Policlinico, Via della Commenda 12, Milan 20122, Italy

E-mail address: giussy.barbara@gmail.com

This article has been accepted for publication and undergone full peer review but has not been through the copyediting, typesetting, pagination and proofreading process, which may lead to differences between this version and the Version of Record. Please cite this article as doi: 10.1111/aogs.13031

This article is protected by copyright. All rights reserved. 
Conflict of interest notification: The authors report no conflict of interest

\begin{abstract}
Introduction: Endometriosis is associated with an increased risk of dyspareunia, therefore this chronic gynaecologic disease should be considered as a major cause of sexual dysfunctions. The aims of this study were to review the literature on the effects of endometriosis surgical and pharmacological treatments on female sexual functioning, and to provide suggestions for future treatment strategies. Material and methods: We followed the PRISMA guidelines to conduct this systematic review, which involved an electronic database search of studies on the association between endometriosis and sexuality published between 2000 and 2016 . Results: As a result of the screening process, 22 studies were included in this systematic review. The 22 studies included were divided in 2 categories: 1) surgical intervention studies $(n=17)$, examining postoperative sexual outcomes of surgery for endometriosis; 2$)$ pharmacological intervention studies $(n=5)$, evaluating the effects of pharmacological endometriosis treatments on sexual functioning. The studies considered showed that overall surgical and pharmacological interventions for endometriosis can lead to medium-/long-term improvement, but not necessarily to a definitive resolution of female sexual dysfunctions due to endometriosis. Conclusions: Sexual functioning is a multidimensional phenomenon and the ideal treatment for endometriosis related sexual dysfunctions should be conducted by a multidisciplinary team that involves not only gynaecologists, but also sexologists and psychologists/psychotherapists. Improving global sexual functioning, and not just reducing pain at intercourse, should be considered as a major clinical goal of endometriosis treatment.
\end{abstract}

\title{
Key-words
}

endometriosis, sexual functioning, sexual dysfunction, dyspareunia, female sexuality, sexual health.

This article is protected by copyright. All rights reserved. 


\begin{abstract}
Abbreviations
DIE: deep infiltrating endometriosis

FSFI: Female Sexual Function Index

GRADE: Grading of Recommendations Assessment, Development, and Evaluation

RCT: randomized controlled trial
\end{abstract}

\title{
Key message
}

Endometriosis surgical and pharmacological treatments can lead to medium-/long-term improvement, but not necessarily to a definitive resolution of female sexual dysfunction. . Thus, the ideal treatment should be conducted by a multidisciplinary team, with the aim of improving global sexual functioning, and not just reducing pain at intercourse.

\section{Introduction}

Sexual functioning is an important dimension that impacts on women's physical and psychological health, and quality of life (1). Female sexual functioning can be negatively affected by a variety of factors, such as operative vaginal delivery (2) and life stressors related to medical illness, including infertility $(1,3)$. Among these stressors, endometriosisa chronic gynaecological disease characterized by the presence of endometrial glands and stroma outside the uterine cavity — is associated with a ninefold increased risk of dyspareunia relative to the general female population $(4,5)$. Deep dyspareunia (i.e., pain experienced inside the vaginal canal, at the level of the cervix, or in the pelvic/uterine/abdominal region, associated with sexual intercourse) caused by endometriosis has been frequently linked to specific types of lesions, such as those infiltrating the uterosacral ligaments, the pouch of Douglas, the posterior vaginal fornix and the anterior rectal wall (1). Pain during intercourse can be triggered by traction of scarred and anelastic endometriotic tissue or by mechanical pressure on lesions occurring during coitus (1). Dyspareunia is also associated with other forms of sexual dysfunctions, such as hypoactive sexual desire, decreased lubrication, arousal difficulties, and orgasm disorders due for instance to fear and anticipation of pain, which represents one of the most powerful inhibitor of the sexual response cycle (6-8). Several 
studies have demonstrated the association between pain at intercourse and anxiety, lower frequency or even avoidance of intercourse, lower levels of desire and arousal, and poorer orgasm (9-11), with negative effects on women's physical and psychological wellbeing, as well as on the couple relationship.

Research investigating the association between endometriosis and global female sexual functioning has outlined an even more complex clinical scenario, suggesting that dyspareunia is not the unique sexual problem associated with the disease. It was estimated that around two thirds of women with endometriosis suffer from some type of sexual dysfunction, such as pain at intercourse, low satisfaction, lack of desire, low arousal, orgasm difficulties, with a negative impact on women's psychological health and intimate relationships $(8,12-14)$. Because endometriosis affects from $5 \%$ to $10 \%$ of women of reproductive age (15), it is imaginable that a large proportion of young women in their most sexually active period of life present sexual dysfunction caused by the disease, which may interfere with conception (5). For this reason, dyspareunia and sexual dysfunctions associated with endometriosis represent a major clinical problem as well as an important outcome of endometriosis treatments. However, to our knowledge, there are no published review articles on the effects of surgical and pharmacological treatments for endometriosis on female sexual functioning.

The aims of the current systematic review are: 1) to describe and compare the effectiveness of surgical and pharmacological endometriosis treatments in relation to female sexual functioning; 2) to provide suggestions for treatment strategies based on research evidence.

\section{Material and methods}

The present review was conducted according to the PRISMA guidelines for systematic reviews (16) and we ensured compliance by completing the PRISMA checklist. We further assessed the quality of evidence of the selected studies using the Grading of Recommendations Assessment, Development, and Evaluation (GRADE) criteria (17). Since only published data were used, the present study was exempt from Institutional Review Board approval. 


\section{Sources}

An electronic database search (PubMed, Medline) was conducted to identify all English-language journal articles published between January 2000 and January 2016 on the impact of endometriosis treatments on female sexual functioning. Appropriate search terms were constructed by reviewing titles, abstracts, and key-words of a sample of articles investigating sexual dysfunctions in patients with endometriosis. Combinations of subject heading terms including 'endometriosis', 'rectovaginal endometriosis', 'deep infiltrating endometriosis', 'sexuality', 'sexual function', 'sexual dysfunction', 'dyspareunia', and 'sexual life' were used. All pertinent papers were retrieved and their reference lists were systematically examined to identify additional articles. No attempt was made to identify unpublished studies.

\section{Study selection and data extraction}

The present review was designed to provide an overview on the effects of endometriosis surgical and pharmacological treatments on female sexual functioning; thus, all published studies evaluating the impact of endometriosis treatments on sexual outcomes were included, without any specific restriction regarding the type of endometriotic lesion and medical intervention. Two authors (G.B. and F.F) conducted an independent screening of all titles and abstracts retrieved from peer-reviewed journals to exclude irrelevant or duplicate citations. Because of the paucity of randomized controlled trials (RCTs) on the sexual effects of medical interventions in patients with endometriosis, we decided to include all selected observational and retrospective studies based on adequacy of description of participants, setting, surgical or pharmacological intervention conducted, and sexual outcomes. In order to investigate all aspects of female sexual functioning, we included only studies in which sexual outcomes were evaluated with a comprehensive sexual questionnaire, focusing not only on dyspareunia, but also on other aspects, such as frequency of intercourses, desire, arousal, lubrication, sexual satisfaction, orgasm. Exclusion criteria were: qualitative research, casereport, commentaries or review articles that did not include original data, measurement of dyspareunia as unique sexual outcome.

Two authors (G.B. and F.F.) designed a data extraction form that was applied to each paper to independently extract data in relation to author, year of publication, location, setting, study design, number of participants, type of endometriosis, sexual functioning questionnaire, type of surgical or pharmacological intervention, time to follow-up, principal aims, and

This article is protected by copyright. All rights reserved. 
outcomes. The quality of evidence of the included studies for the outcome of interest was assessed following the criteria described by the GRADE method (17. According to the GRADE criteria, the quality of evidence is divided into four categories: high, moderate, low, and very low.

\section{Results}

A total of 615 articles were identified by database search as potentially relevant. Of these 615 articles, 60 had titles or abstracts reporting findings related to the association between endometriosis and sexuality, as well as to the assessment of sexual functioning after pharmacological or surgical treatment of endometriosis. Overall, 38 articles were not included in the current review: 3 studies because the language used was not English (18-20 ); 11 because they were review articles or commentaries (5, 11, 21-29); 2 because they were qualitative studies (30-31); 14 because dyspareunia was the only sexual outcome evaluated, no comprehensive sexual questionnaires were used, or no specific information from the questionnaires used was reported $(1,32-44) ; 8$ because they were studies on the impact of having endometriosis on sexual functioning, without considering the effect of any medical intervention (7, 8, 12-14, 45-47). Complete author agreement (G.B. and F.F.) regarding included and excluded studies was achieved. Figure 1 shows the flow diagram of the literature search results. Because almost all studies included in this review are observational studies, the final assessment - according to the GRADE criteria (17)—was low level of quality.

\section{Characteristics of studies}

Substantial differences were found in methodology, population, and outcome measures of the studies included. The characteristics of the selected studies are extensively reported in Table 1 in relation to the following variables: author, year, country, study aims, study design, sample, type of endometriosis, sexual functioning measures, time to follow-up. Overall, there were 16 prospective observational cohort studies (48-63), 2 retrospective cohort studies $(64,65), 2$ RCT $(66,67)$, one patients' preference parallel cohort study $(68)$, and one before and after study (69). The number of subjects with endometriosis enrolled in the studies ranged from 7 (50) to 250 (60). The most used questionnaire evaluating sexual functioning was the Female Sexual Function Index (FSFI). 
Seventeen studies examined the effects of surgery for endometriosis on female sexual functioning $(48-58,60,61,63-65,68)$, whereas the impact of pharmacological therapy on sexual functioning was assessed in only 5 studies $(59,62,66,67,69)$. Four studies analysed the effects of combined surgical and post-operative pharmacological treatment on sexual functioning $(52,55,60,68)$.

The main sexual outcomes of the studies included in the review are reported in Table 2. The heterogeneity of the studies in relation to research methods, types of endometriosis, types of treatment, questionnaires used, and sexual outcomes considered did not allow to adopt a meta-analytic approach to summarize the results. Thus, we decided to classify the studies on the basis of the type of therapeutic intervention performed, so that two categories were identified: 1) surgical intervention and 2) pharmacological intervention studies.

\section{Surgical intervention studies}

We found 17 articles evaluating postoperative sexual outcomes of surgery for endometriosis $(48-58,60,61,63-65,68)$, which was performed at laparoscopy in most of these studies (48$55,57,60,63,64,65)$. Time to follow-up ranged from 4 (48) to 60 (49) months after surgery and participants were mainly patients with deep infiltrating endometriosis (DIE), rectovaginal or bowel endometriosis; sexual outcomes were often part of post-operative quality of life indicators. Indications for surgery were more frequently persistent pelvic pain or infertility rather than sexual complaints. Overall, postoperative global sexual functioning was assessed in 1505 women who underwent different types of surgery for endometriosis symptoms.

Specifically, Garry et al. (48) explored the effects of endometriosis radical laparoscopic excision on quality of life indicators, including sexual outcomes. Primary indication for surgery was pelvic pain (75.4\% of women), whereas dyspareunia was an indication for surgery in only $10.5 \%$ of cases. The sexual questionnaire used was the Sexual Activity Questionnaire that provides separate scores for pleasure, frequency, and discomfort with sex. Four months after surgery there was significant improvement on all domains of the sexual questionnaire.

Abbott et al. (49) conducted a prospective observational cohort study on 176 women with surgical diagnosis of endometriosis. Laparoscopic excision was performed on all endometriosis patients with no hormonal pre-treatment and sexual outcomes were evaluated

This article is protected by copyright. All rights reserved. 
up to 5 years after surgery. The majority of patients (74\%) suffered from non-menstrual pelvic pain and only $3.5 \%$ from dyspareunia; $70 \%$ of patients had had one previous surgery. Data on revised American Fertility Society (rAFS) stage of endometriosis were recorded during surgery (see Table 1); $6 \%$ of patients had a full thickness vaginal lesion and $88 \%$ of women had an involvement of the uterosacral ligaments. Women showed improved sexual functioning (pleasure and habit) and decreased discomfort with intercourse at 60 months after surgery, although the probability of requiring further surgery was $36 \%$.

Ferrero et al. (51) evaluated deep dyspareunia and quality of sexual life in 68 women with endometriosis who underwent laparoscopic full excision of endometriotic lesions. A sexual questionnaire based on the DSFI was administered before surgery, and at 6- and 12month follow-up. Patients were also asked to rate their overall level of sexual satisfaction on a 9-point scale (the Global Sexual Satisfaction Index (GSSI)). At 6- and 12-month follow-up, $75 \%$ of women (either with or without endometriosis of the uterosacral ligaments) reported decreased deep dyspareunia. Women with endometriosis of the uterosacral ligaments exhibited increased variety in sexual life, higher frequency of intercourse, more satisfying orgasms, and were more relaxed and fulfilled after sex. A similar tendency was identified in women without endometriotic lesions of the uterosacral ligaments, but statistical significance was not always reached.

The impact of laparoscopic radical resection for endometriosis on different sexual outcomes (i.e., dyspareunia, sexual function, quality of sex life, and interpersonal relationships) was also investigated by Fritzer et al. (63) in a multicentre study on 96 women who underwent surgery for endometriosis and concomitant dyspareunia. At 12-month followup women reported decreased pain and improved quality of sex life. No postoperative hormonal treatment was administered and the authors concluded that radical laparoscopic excision of endometriosis is effective as it leads to improved dyspareunia and quality of women's sexual experience.

Setälä et al. (56) examined sexual functioning in women with deep endometriosis nodules of the vagina after surgery, including vaginal resection. Before surgery and at 12month follow-up, women's sexual functioning was evaluated using the McCoy Female Sexuality Questionnaire (MFSQ), which assesses sexual satisfaction (sexual enjoyment, satisfaction with frequency of intercourse, frequency of sexual thoughts, arousal during sex,

This article is protected by copyright. All rights reserved. 
frequency of orgasm), sexual problems (poor lubrication, painful sexual intercourse), and satisfaction with the partner as a lover and friend. A significant increase in sexual satisfaction and decrease in sexual problems was detected at follow-up. No significant differences were observed in relation to the satisfaction with the partner. Three patients (14\%) reported newonset sexual dysfunctions (i.e., decreased libido, decreased vaginal lubrication, dyspareunia).

Che et al. (58) evaluated the sexual functioning of 108 women with DIE by comparing 63 participants who underwent conventional surgery (i.e., complete resection of all detectable endometriotic lesions with a standard surgical procedure at laparoscopy or laparotomy) with 45 patients who underwent nerve-sparing surgery. The Female Sexual Function Index (FSFI) was administered at 6-, 12-, and 24-month follow-up, with significant improvement in all the FSFI domains and the FSFI total score at the 24-month follow-up (except for satisfaction in the conventional surgery group). However, in both groups the total FSFI scores at 24-month follow-up were below the cut-off score indicating sexual dysfunction. Severe postoperative complications such as bladder dysfunction (selfcatheterization or alteration in voiding symptoms) were also observed in $15.9 \%$ of women who underwent conventional surgery.

Six studies evaluated the impact of laparoscopic bowel resection for severe endometriosis on sexual functioning (50, 53, 54, 57, 64, 65). Meuleman et al. (64) retrospectively evaluated sexual function following multidisciplinary $\mathrm{CO}_{2}$ laser radical laparoscopic excision of deep infiltrating colorectal endometriosis, with a median 29-month follow-up. All 56 procedures were carried out by laparoscopy, and no protective ileostomy was needed in this group of patients. When post-operative hormonal contraception was desired, a low dose oral contraception or a levonorgestrel-releasing intrauterine device was prescribed. No data were provided about the proportion of patients requiring post-surgery hormonal treatment. Sexual functioning improved significantly after surgery with respect to pleasure, discomfort, and frequency of sexual intercourse. In a similar retrospective study published in 2011 (65), the authors confirmed that a radical $\mathrm{CO}_{2}$ laparoscopic excision of endometriosis with colorectal wall invasion combined with laparoscopic segmental bowel resection and reanastomosis is effective in ameliorating sexual life, in relation to sexual pleasure, frequency of sexual activity and discomfort during sexual intercourse.

This article is protected by copyright. All rights reserved. 
Kössi et al. (54) prospectively evaluated sexual functioning in 26 patients who underwent rectal or sigmoid resection for endometriosis. At 12 months after surgery, there was a statistically significant improvement in the sexual satisfaction subscale of the McCoy Female Sexuality Questionnaire. A numerical decrease, although not statistically significant, was detected on the Sexual problems subscale, in particular with regard to "painful sexual intercourse". No differences were found in the partner satisfaction subscale. Two patients reported new-onset deep dyspareunia.

Only one study (53) compared the effects of two different surgical techniques (i.e., the laparoscopic nerve-sparing approach and the classical laparoscopic approach) on sexual functioning in patients with severe deep endometriosis. A total of 126 women were included in the research, 61 treated with nerve-sparing radical excision of pelvic endometriosis with segmental bowel resection and 65 treated with the classical technique. At 12-month followup, women's sexual functioning was evaluated in terms of change in frequency of sexual intercourse, presence of dyspareunia, vaginal dryness, vaginal blood loss after intercourse, use of lubricants, sexual desire, orgasm frequency, and patient's assessment of comprehensive sexual satisfaction, without using any validated sexual questionnaire. No group differences were found on frequency of sexual intercourses after surgery and number of patients claiming dyspareunia, psychological distress, and vaginal dryness. Patients who underwent traditional surgery reported more frequent vaginal bleeding and lowered sexual desire. Surprisingly, reduced sexual pleasure/frequency of orgasm was more often exhibited by patients treated with the nerve sparing approach relative to those treated with traditional surgery.

Van den Broeck et al. (57) compared two surgical procedures (i.e., laparoscopic surgery with bowel resection and laparoscopic surgery without bowel resection) performed on 203 patients with moderate or severe endometriosis on sexual functioning. Both procedures led to improved postoperative sexual functioning relative to preoperative sexual functioning. Specifically, women in the bowel resection group showed significantly better sexual arousal. No significant differences between the two groups were found in relation to sexual desire, orgasm problems, and pain during intercourse. In another study (50), fertilitysparing laparoscopic surgery with bowel resection for severe endometriosis was associated with increased sexual functioning at 12-month follow-up, although full statistical significance was not reached due to the small sample size $(n=7)$.

This article is protected by copyright. All rights reserved. 
A recent study by Morelli et al. (61) reported preliminary results of a singleinstitution experience that involved robotic radical treatment (i.e., the DaVinci system) of 10 patients suffering from DIE with colorectal involvement. All women (with the exception of patients who were trying to conceive) were treated with either a continuous low-dose of oral contraceptives or oral progestin for 6 months after surgery Findings revealed worsened sexual functioning at one-month follow-up as compared with preoperative sexual functioning, which returned comparable with preoperative sexual functioning at 12-month follow-up. A statistically significant improvement one year after surgery was observed only as regards dyspareunia.

Several authors have investigated the impact of surgical treatments for endometriosis and subsequent pharmacological therapies on sexual functioning $(52,55,60)$. Ferrero et al. (52) examined the effects of laparoscopic excision of endometriosis combined with a postoperative 6-month treatment with triptorelin. Main sexual outcome measures were deep dyspareunia and quality of sex life. At 12 months after completing the postoperative treatment, $45.9 \%$ of women did not have deep dyspareunia, $34.7 \%$ showed decreased dyspareunia, and $62.2 \%$ reported increased frequency of sexual intercourse, as well as improvements in several aspects of sexual life, such as orgasm and satisfaction.

Mabrouk et al. (55) investigated the impact of laparoscopic full excision of endometriosis and subsequent combined oral contraceptive therapy on sexual functioning among 106 women with DIE. At 6 months after surgery and subsequent postoperative pharmacological treatment, there were improvements in sexual desire, satisfaction with sex, and pelvic problem interference with intercourse. No significant pre-postoperative differences were found in relation to orgasm between women who underwent intestinal resection and those who had intestinal nodule excision.

Di Donato et al. (60) evaluated the impact of laparoscopic surgery for endometriosis (with postoperative hormonal treatment) on sexual functioning by comparing 250 patients affected by DIE with 250 healthy controls. The DIE group showed improved desire, satisfaction, and pelvic problem interference at 6 months after surgery, to the point that these scores were comparable to those reported by healthy women (with the exception of orgasm). 
Vercellini et al. (68) examined the effects of surgical versus low-dose progestin treatment on sexual functioning in women with endometriosis and associated severe deep dyspareunia. Treatments (laparoscopic surgery or norethisterone acetate $2.5 \mathrm{mg} /$ day per os) were not randomly allocated, as the design of the study was a patient preference, parallel cohort study with a 12-month follow-up. Findings showed improved sexual function immediately after surgery, but the effect declined over time. A more gradual, but progressive increase was observed during progestin use and no significant between-group differences emerged at 12-month follow-up. The authors concluded that both surgery and low dose norethisterone acetate treatment can be considered as valuable strategies for reducing the negative effects of deep dyspareunia related to endometriosis on women's sexual functioning.

Taken together, the above mentioned studies showed that surgery for endometriosis may lead to improved sexual functioning, although the extent and the length of these positive effects were often poorly defined. Most articles had an exclusive focus on DIE and radical laparoscopic surgery (including bowel resection). Although several studies considered of a post-operative pharmacological adjuvant therapy, a comparison between surgery and hormonal treatment was systematically addressed only in one study (68).

\section{Pharmacological intervention studies}

We found only 5 studies $(59,62,66,67,69)$ investigating the effects of pharmacological treatments for endometriosis on global female sexual functioning. Overall, 396 women were examined. This paucity of data may seem surprising if one considers the huge amount of research evidence for the efficacy of medical treatment for symptomatic endometriosis. However, almost all of these studies focused exclusively on the effects of treatments on deep dyspareunia, without considering global female sexual functioning. Moreover, most studies evaluated the effects of hormonal therapy after surgical treatment for endometriosis, and for this reason were included in the "Surgical intervention studies" section of this review.

Two of the studies investigating the sexual impact of pharmacological treatment for endometriosis are RCTs. The RCT conducted by Vercellini et al. (68) compared the effects of cyproterone acetate with continuous monophasic oral contraceptive. Sexual outcomes were examined after 6 months of treatment and improved sexual functioning was identified in both groups, with no statistically significant differences. The RCT conducted by Guzick et al. (67) 
compared the efficacy of leuprolide and continuous oral contraceptives with regard to sexual satisfaction, with no between-group differences.

Three studies have recently evaluated the efficacy of dienogest, a new progestin specifically proposed for the treatment of endometriosis, on sexual functioning. Morotti et al. (59) assessed sexual function after 6-months of dienogest treatment in women with symptomatic rectovaginal endometriosis, who had pain persistence and were unsatisfied after 6 months of treatment with norethisterone acetate therapy. Patients treated with dienogest exhibited increased lubrication, decreased pain, and overall improved sexual functioning. Dienogest was generally well tolerated, with no reported serious adverse effects.

Vercellini et al. (69) assessed sexual functioning in 90 patients with symptomatic endometriosis who were treated with norethindrone acetate and 90 who were treated with dienogest. After 6 months of therapy, all participants reported increased sexual functioning, although with no significant group differences, and the average total FSFI score remained below the threshold for sexual dysfunction in both groups.

Caruso et al. (62) investigated quality of life and sexual functioning in 54 women affected by endometriosis-associated pelvic pain during a 6-month treatment with $2 \mathrm{mg} /$ daily of dienogest. The control group was composed of women with pelvic pain due to endometriosis who refused to assume hormonal treatments for different reasons and were treated only with non-steroidal anti-inflammatory drugs. Women in the dienogest group showed reduced pain symptoms and increased sexual functioning, whereas no significant changes were observed in the control condition.

\section{Discussion}

The aims of the current review were to describe and compare the effectiveness of different treatments of endometriosis in relation to sexual functioning and to suggest useful treatment strategies based on research evidence, as well as new avenues for future studies. In our systematic review, we adopted a comprehensive approach as we considered multiple dimensions of female sexuality, and not just pain at intercourse. Such a wide-ranging perspective is consistent with the evidence provided by the research literature, which has shown that: a) reduction of pain at intercourse, though important, does not necessarily lead to 
improved overall sexual functioning (6); b) female sexual function is a multifactorial process that involves different psychological dimensions (e.g., personality traits, body image, selfesteem, relational adjustment) and sexual mechanisms (e.g., interest in sex, desire, arousal, pleasure, satisfaction with sex and with partner), which are pivotal for good sexuality.

Overall, the studies examined in this review highlighted that endometriosis, especially when associated with deep dyspareunia and/or chronic pelvic pain, has strong negative effects on several domains of female sexual functioning, such as desire, orgasm, satisfaction with sex, and frequency of sexual intercourses. Particular types of endometriotic lesions, such as DIE and rectovaginal endometriosis, are associated with the poorest sexual functioning, perhaps because the women affected suffer from deep dyspareunia more frequently than those who have other forms of endometriosis or healthy women $(7,12,14)$.

However, several authors $(30,70)$ have recently suggested that the assessment of dyspareunia itself does not allow for a comprehensive and precise evaluation of female sexual functioning. Although dyspareunia is perceived as very distressing by many women, there may be variability in the way it is experienced, as women may display different coping strategies. For example, some women may decide to avoid pain by limiting, or even avoiding, sexual intercourses; other women may try to find their own way to deal with the pain during sex (for instance, by changing position) for several reasons, such as the importance given to sexual intimacy, or the wish for a pregnancy (30). Different coping strategies may lead to differences in the psychological impact of dyspareunia, for example as regards mental health, self-esteem, feelings of femininity, and sense of guilt toward the partner. These issues have been poorly investigated so far and future studies should examine the role of individual differences, especially in terms of personality traits and coping strategies, to reach broader understanding of sexual dysfunction associated with endometriosis. In this light, interdisciplinary research conducted by different cooperating professionals (such as gynaecologists, psychologists, and sexologists) may lead to increased knowledge, as well as to the development of effective treatment programmes.

Overall, research has shown that surgical and pharmacological interventions are both valuable options to ameliorate sexual outcomes in a medium-/long-term period in women with endometriosis, although the extent and the duration of the observed positive effects have been poorly defined. The reviewed articles focused more on surgical rather than

This article is protected by copyright. All rights reserved. 
pharmacological treatment, thus limited evidence is available on the efficacy of hormonal therapy on endometriosis-related sexual dysfunction. This paucity of data may be due to the fact that the types of endometriosis more frequently associated with sexual impairment (i.e., DIE and rectovaginal endometriosis) have been historically treated with surgery, although some authors have underlined that medical treatments other than surgery may lead to substantial relief of pain in women with these forms of endometriosis $(23,33,70-73)$.

Overall, heterogeneity of population, instruments, and sexual outcomes considered did not allow to pool data and estimate the sexual effects of the interventions evaluated by the studies included in this review. However, some conclusions can be drawn from our analysis. Surgical treatment may improve sexual functioning in women with endometriosis, irrespective of the type of surgery (standard surgical procedure at laparoscopy or laparotomy; radical, conservative, or nerve sparing surgery). Postoperative improvement in sexual functioning is presumably linked to cessation of pain, especially dyspareunia, due to the excision of endometriotic foci. Several studies $(11,14)$ have shown that this sexual benefit appears more evident when the endometriotic lesions are localized in the posterior pelvic compartment (i.e., pouch of Douglas, uterosacral ligaments, posterior vaginal fornix, recto sigmoid portion of the bowel), thus confirming the hypothesis that pain at intercourse may have an organic, mechanistic origin. Future studies with longer follow-up times should investigate whether the positive sexual effects of surgery are long-lasting or tend to fade over time, which represents an important clinical issue.

It should also be reminded that complete radical excision of DIE frequently involves concomitant bowel or parametrial resections and/or vaginal opening; these procedures are often associated with a high risk of intra- and postoperative major complications, such as ureteral, bladder, or bowel injuries or potential risk of pelvic denervation $(1,14,63)$. Therefore, this surgery requires high level technical competence and should be performed in specialized referred centres for surgical treatment of endometriosis; patients should be exhaustively informed about types and incidence of possible complications, and gynaecological surgeons should be able to adequately manage bowel or urinary damages or, alternatively, they should work in a multidisciplinary team that includes a general and/or urological surgeon.

This article is protected by copyright. All rights reserved. 
Risks and benefits of any surgical procedure must always be considered and clearly explained to women in order to obtain a full informed consent. This is important if one considers that the expected advantages of surgery may influence women's choices. For example, expectations of pain relief, infertility resolution, or amelioration of sexual health may affect patients' decisions to undergo high risk elective surgery. Moreover, women should be informed that, unfortunately, the global effectiveness of surgical treatment of DIE is operator-dependent. Overall, in the absence of absolute medical indications, surgery can be considered as a good option to improve dyspareunia and global sexual functioning when hormonal treatment is not feasible (such as for women who are attempting spontaneous conception), or when estro-progestin or progestin treatment is ineffective, contraindicated or not tolerated because of side effects.

The evidences (although limited) provided by the studies on the efficacy of different hormonal treatments with respect to female sexual functioning suggest that pharmacological intervention could be a good option for women who are not seeking conception, or underwent multiple surgeries for endometriosis without long-lasting benefit, or refuse surgery due to potential complications. Further research is needed in order to investigate the role of hormonal therapy, as well as the effects of the various available compounds.

Overall, the generalizability of the results provided by the studies examined in this review is limited. In most studies evaluating surgical treatments, the presence of sexual dysfunction was not the reason for surgical intervention and sexual functioning was not the primary study outcome, which involves limitation in the external validity of the reported benefits. The population examined represents another limitation, since several studies included only women with deep dyspareunia, while other articles did not provide clear information about pain severity or types of endometriotic lesions. In several studies $(52,55$, 60) women underwent a combined surgical and postoperative hormonal treatment, such that it was not possible to clearly identify the proportion of variance explained by surgery versus hormonal therapy. Furthermore, many studies did not report whether patients underwent a pre- or postoperative hormonal treatment, which entails partial understanding of the results. More research is necessary to explore in-depth sexual functioning in women with endometriosis. Future studies should consider the impact of other dimensions, such as infertility, which significantly affects intimate relationships, as well as the role of the partner. 


\section{Conclusions}

Sexual functioning is negatively affected by endometriosis, which means that a large proportion of women of reproductive age present sexual dysfunction. The research literature on endometriosis, as well as our own clinical practice, undoubtedly indicate that these young women very often do not have the chance to experience pleasure associated with sexual activity. Furthermore, the extant literature on the effects of surgical and pharmacological interventions for endometriosis suggests that medical treatment is indeed useful, but may not necessarily lead to long-term, definitive resolution of women's sexual problems.

Since sexual functioning is a multidimensional phenomenon deriving from the interaction of multiple physical/anatomical, psychosocial, and emotional factors (74), and considering that endometriosis affects multiple physical and psychological dimensions (75), we think that the best treatment programme can be provided by multidisciplinary teams composed of gynaecologists, sexologists, and psychologists/psychotherapists.

A more comprehensive perspective not exclusively focused on pain may help rule out sexual dysfunction in a more complete and precise manner, with subsequent identification of the most appropriate approach to treatment. As demonstrated by several studies (6), different types of sexual dysfunction (such as pain during intercourse, hypoactive sexual desire disorder, lack of arousal, or lack of orgasm) require different treatment programmes. Therefore, comprehensive sexual health assessment should be routinely conducted with all women referring to dedicated endometriosis centres and the improvement of sexual functioning should be considered as a major therapeutic goal. Sexual questionnaires may be effectively used by all gynaecologists during preliminary assessment to outline women's sexological profile, as well as to facilitate patient expression of thoughts, feelings, complaints or questions regarding sexual life. This is particularly important if one considers that patients may feel embarrassed and therefore reluctant to express any type of feeling or concern regarding sexuality to their gynaecologists. At the same time, gynaecologists may be more likely to prioritise addressing other endometriosis-related issues, such as pelvic pain and its medical treatment, with a general lack of knowledge about sexual medicine that may not allow formulating appropriate questions to rule out sexual dysfunction and indicate adequate therapeutic options.

This article is protected by copyright. All rights reserved. 
We believe that gynaecological practice with endometriosis patients may be improved by providing gynaecologists with training in sexual medicine . If sexual dysfunction is ruled out during preliminary assessment, further investigation should be conducted by professionals specialized in sexual counselling and therapy focusing not only on the symptoms presented by the patient, but also on the association between sexual problems and other important psychological, relational, and cultural dimensions, such as for instance selfesteem, body image, quality of intimate relationship and dyadic coping strategies, and cultural beliefs about femininity and sexuality.

\section{Funding}

No specific funding was obtained for this research.

\section{References}

1. Vercellini P, Somigliana E, Consonni D, Frattaruolo MP, De Giorgi O, Fedele L. Surgical versus medical treatment for endometriosis-associated severe deep dyspareunia: I. Effect on pain during intercourse and patient satisfaction. Hum Reprod 2012;27:3450-9. 2. Barbara G, Pifarotti P, Facchin F, Cortinovis I, Dridi D, Ronchetti C, et al. Impact of mode of delivery on female postpartum sexual functioning: spontaneous vaginal delivery and operative vaginal delivery versus caesarean section. J Sex Med 2016;13:393-401.

3. Millheiser LS, Helmer AE, Quintero RB, Westphal LM, Milki AA, Lathi RB. Is infertility a risk factor for female sexual dysfunction? A case-control study. Fertil Steril 2010;94:2022-5.

4. Ballard KD, Seaman HE, de Vries CS, Wright JT. Can symptomatology help in the diagnosis of endometriosis? Findings from a national case-control study-Part 1. BJOG. 2008;115:1382-91.

5. Vercellini P, Meana M, Hummelshoj L, Somigliana E, Viganò P, Fedele L. Priorities for endometriosis research: a proposed focus on deep dyspareunia. Reprod Sci 2011;18:1148.

6. Buster JE. Managing female sexual dysfunction. Fertil Steril 2013;100:905-15.

7. Di Donato N, Montanari G, Benfenati A, Monti G, Bertoldo V, Mauloni M, et al. Do women with endometriosis have to worry about sex? Eur J Obstet Gynecol Reprod Biol 2014;179:69-74.

This article is protected by copyright. All rights reserved. 
8. Fritzer N, Haas D, Oppelt P, Renner S, Hornung D, Wölfler M, et al. More than just bad sex: sexual dysfunction and distress in patients with endometriosis. Eur J Obstet Gynecol Reprod Biol 2013;169:392-6.

9. Meana M, Binik YM, Khalife S, Cohen DR. Biopsychosocial profile of women with dyspareunia. Obstet Gynecol 1997;90:583-9.

10. Laumann EO, Paik A, Rosen RC. Sexual dysfunction in the United States: prevalence and predictors. JAMA 1999;281:537-44.

11. Ferrero S, Ragni N, Remorgida V. Deep dyspareunia: causes, treatments, and results. Curr Opin Obstet Gynecol 2008;20:394-9.

12. Montanari G, Di Donato N, Benfenati A, Giovanardi G, Zannoni L, Vicenzi C, et al. Women with deep infiltrating endometriosis: sexual satisfaction, desire, orgasm, and pelvic problem interference with sex. J Sex Med 2013;10:1559-66.

13. Jia SZ, Leng JH, Sun PR, Lang JH. Prevalence and associated factors of female sexual dysfunction in women with endometriosis. Obstet Gynecol 2013;121:601-6.

14. Vercellini P, Somigliana E, Buggio L, Barbara G, Frattaruolo MP, Fedele L."I can't get no satisfaction": deep dyspareunia and sexual functioning in women with rectovaginal endometriosis. Fertil Steril 2012;98:1503-11.e1.

15. Viganò P, Parazzini F, Somigliana E, Vercellini P. Endometriosis: epidemiology and etiological factors. Best Prac Res Clin Obstet Gynaecol 2004;18:177-200.

16. Moher D, Liberati A, Tetzlaff J, Altman DG, PRISMA Group. Preferred reporting items for systematic reviews and meta-analyses: the PRISMA statement. PLoS Med 2009;6:e1000097.

17. Guyatt GH, Oxman AD, Vist GE, Kunz R, Falck-Ytter Y, Alonso-Coello P, et al. GRADE: an emerging consensus on rating quality of evidence and strength of recommendations. BMJ. 2008;336:924-6.

18. Bailly E, Marguilies A, Letohic A, Fraleu-Louër B, Renouvel F, Panel P. Evolution des symptoms et de la qualité de vie des patients après chirurgie de l'endométriose digestive. [Evolution of symptoms and quality of life of patients after surgery of digestive endometriosis]. In French. Gynecol Obstet Fertil. 2013;41:627-634.

19. Dubuisson J, Pont M, Roy P, Golfier F, Raudrant D. Sexualité féminine après chirurgie pour endométriose pelvienne profonde. [Female sexuality after surgical treatment of symptomatic deep pelvic endometriosis]. In French. Gynecol Obstet Fertil. 2013;41:38-44.

20. Pluchino N, Wenger J, Freschi L. Effetti della terapia medica e chirurgica sulla funzione sessuale in pazienti affette da endometriosi. [Effects of medical and surgical therapy

This article is protected by copyright. All rights reserved. 
on sexual function in patients with endometriosis.] In Italian. Bollettino di Ginecologia Endocrinologica. 2014;8:27-30.

21. Fernandez I, Reid C, Dziurawiec S. Living with endometriosis: the perspective of male partners. J Psychosom Res. 2006;61:433-8.

22. Culley L, Law C, Hudson N, Denny E, Mitchell H, Baumgarten M, et al. The social and psychological impact of endometriosis on women's lives: a critical narrative review. Hum Reprod Update. 2013;19:625-39.

23. Vercellini P, Crosignani PG, Somigliana E, Berlanda N, Barbara G, Fedele L. Medical treatment for rectovaginal endometriosis: what is the evidence? Hum Reprod. 2009;24:250414.

24. Vercellini P, Crosignani PG, Abbiati A, Somigliana E, Viganò P, Fedele L. The effect of surgery for symptomatic endometriosis: the other side of the story. Human Reprod. 2009; 15:177-88.

25. De Cicco C, Corona R, Schonman R, Mailova K, Ussia A, Koninckx P. Bowel resection for deep endometriosis: a systematic review. BJOG. 2011;118:285-91.

26. Pauls RN. Impact of gynaecological surgery on female sexual function. Int $\mathbf{J}$ Impotence Research. 2010;22:105-14.

27. Deguara CS, Pepas L, Davis C. Does minimally invasive surgery for endometriosis improve pelvic symptoms and quality of life? Curr Opin Obstet Gynecol. 2012;24:241-4. 28. Hummelshoj L, De Graaff A, Dunselman G, Vercellini P. Let's talk about sex and endometriosis. J Fam Plann Reprod Health Care. 2014;40:8-10.

29. Fritzer N, Tammaa A, Salzer H, Hudelist G. Dyspareunia and quality of sex life after surgical excision of endometriosis: a systematic review. Eur J Obstet Gynecol Reprod Biol. 2014;173:1-6.

30. Denny E, Mann C. Endometriosis-associated dyspareunia: the impact on women's lives. J Fam Plann Reprod health Care. 2007;33:189-193.

31. Moradi M, Parker M, Sneddon A, Lopez V, Ellwood D. Impact of endometriosis on women's lives: a qualitative study. BMC Womens Health. 2014;14:123.

32. Anaf V, Simon P, El Nakadi I, Simonart T, Noel J, Buxant F. Impact of surgical resection of rectovaginal pouch of douglas endometriotic nodules on pelvic pain and some elements of patients' sex life. J Am Assoc Gynecol Laparosc. 2001;8:55-60.

33. Vercellini P, Pietropaolo G, De Giorgi O, Pasin R, Chiodini A, Crosignani PG. Treatment of symptomatic rectovaginal endometriosis with an estrogen-progestogen combination versus low-dose norethindrone acetate. Fertil Steril. 2005;84:1375-87.

This article is protected by copyright. All rights reserved. 
34. Angioni S, Peiretti M, Zirone M, Palomba M, Mais V, Gomel V, et al. Laparoscopic excision of posterior vaginal fornix in the treatment of patients with deep endometriosis without rectum involvement: surgical treatment and long-term follow-up. Hum Reprod. 2006;21:1629-34.

35. Dubernard G, Piketty M, Rouzier R, Houry S, Bazot M, Darai E. Quality of life after laparoscopic colorectal resection for endometriosis. Hum Reprod. 2006;21:1243-7.

36. Landi S, Ceccaroni M, Perutelli A, Allodi C, Barbieri F, Fiaccavento A, et al. Laparoscopic nerve-sparing complete excision of deep endometriosis: is it feasible? Hum Reprod. 2006;21:774-81.

37. Kristensen J, Kjer JJ. Laparoscopic laser resection of rectovaginal pouch and rectovaginal septum endometriosis: the impact on pelvic pain and quality of life. Acta Obstet Gynecol Scand. 2007;86:1467-71.

38. Remorgida V, Abbamonte HL, Ragni N, Fulcheri E, Ferrero S. Letrozole and norethisterone acetate in rectovaginal endometriosis. Fertil Steril. 2007;88:724-6.

39. Ferrero S, Camerini G, Seracchioli R, Ragni N, Venturini PL, Remorgida V. Letrozole combined with norethisterone acetate compared with norethisterone acetate alone in the treatment of pain symptoms caused by endometriosis. Hum Reprod. 2009;24:3033-41. 40. Ferrero S, Camerini G, Ragni N, Venturini PL, Biscaldi E, Remorgida V. Norethisterone acetate in the treatment of colorectal endometriosis: a pilot study. Hum Reprod. 2010;25:94-100.

41. De Graaff AA, D'Hooghe TM, Dunselman GA, Dirksen CD, Hummelshoj L, WERF EndoCost Consortium, et al. The significant effect of endometriosis on physical, mental and social wellbeing: results from an international cross-sectional survey. Hum Reprod. 2013;28:2677-85.

42. Angioli R, De Cicco Nardone C, Cafà EV, Plotti F, Muzii L, Montera R, et al. Surgical treatment of rectovaginal endometriosis with extensive vaginal infiltration: results of a systematic three-step vagino-laparoscopic approach. Eur J Obstet Gynecol Reprod Biol. 2014;173:83-7.

43. Kent A, Shakir F, Rockall T, Haines P, Pearson C, Rae-Mitchell W, et al. Laparoscopic surgery for severe rectovaginal endometriosis compromising the bowel: A prospective cohort study. J Minim Invasive Gynecol. 2016;23:526-34.

44. Vercellini P, Aimi G, Busacca M, Apolone G, Uglietti A, Crosignani PG. Laparoscopic uterosacral ligament resection for dysmenorrhea associated with endometriosis: results of a randomized, controlled trial. Fertil Steril. 2003;80:310-319. 
45. Tripoli TM, Sato H, Sartori MG, de Araujo FF, Girão MJ, Schor E. Evaluation of quality of life and sexual satisfaction in women suffering from chronic pelvic pain with or without endometriosis. J Sex Med. 2011;8:497-503.

46. Evangelista A, Dantas T, Zendron C, Soares T, Vaz G, Oliveira MA. Sexual function in patients with deep infiltrating endometriosis. J Sex Med. 2014;11:140-5.

47. Ferrero S, Esposito F, Abbamonte LH, Anserini P, Remorgida V, Ragni N. Quality of sex life in women with endometriosis and deep dyspareunia. Fertil Steril. 2005;83:573-9.

48. Garry R, Clayton R, Hawe J. The effect of endometriosis and its radical laparoscopic excision on quality of life indicators. BJOG. 2000;107:44-54.

49. Abbott JA, Hawe J, Clayton RD, Garry R. The effects and effectiveness of laparoscopic excision of endometriosis: a prospective study with 2-5 year follow-up. Hum Reprod. 2003;18:1922-7.

50. Lyons SD, Chew SS, Thomson AJ, Lenart M, Camaris C, Vancaillie TG, et al. Clinical and quality-of-life outcomes after fertility-sparing laparoscopic surgery with bowel resection for severe endometriosis. J Minim Invasive Gynecol. 2006;13:436-41.

51. Ferrero S, Abbamonte LH, Giordano M, Ragni N, Remorgida V. Deep dyspareunia and sex life after laparoscopic excision of endometriosis. Hum Reprod. 2007;22:1142-8.

52. Ferrero S, Abbamonte LH, Parisi M, Ragni N, Remorgida V. Dyspareunia and quality of sex life after laparoscopic excision of endometriosis and postoperative administration of triptorelin. Fertil Steril. 2007;87:227-9.

53. Ceccaroni M, Clarizia R, Bruni F, D'Urso E, Gagliardi ML, Roviglione G, et al. Nerve-sparing laparoscopic eradication of deep endometriosis with segmental rectal and parametrial resection: the Negrar method. A single-center, prospective, clinical trial. Surg Endosc. 2012;26:2029-45.

54. Kössi J, Setälä M, Mäkinen J, Härkki P, Luostarinen M. Quality of life and sexual function 1 year after laparoscopic rectosigmoid resection for endometriosis. Colorectal Dis. 2013;15(1):102-8.

55. Mabrouk M, Montanari G, Di Donato N, Del Forno S, Frascà C, Geraci E, et al. What is the impact on sexual function of laparoscopic treatment and subsequent combined oral contraceptive therapy in women with deep infiltrating endometriosis? J Sex Med. 2012;9:770-8.

56. Setälä M, Härkki P, Matomäki J, Mäkinen J, Kössi J. Sexual functioning, quality of life and pelvic pain 12 months after endometriosis surgery including vaginal resection. Acta Obstet Gynecol Scand. 2012;91:692-8.

This article is protected by copyright. All rights reserved. 
57. Van den Broeck U, Meuleman C, Tomassetti C, D'Hoore A, Wolthuis A, Van Cleynenbreugel B, et al. Effect of laparoscopic surgery for moderate and severe endometriosis on depression, relationship satisfaction and sexual functioning: comparison of patients with and without bowel resection. Hum Reprod. 2013;28:2389-97.

58. Che X, Huang X, Zhang J, Xu H, Zhang X. Is nerve-sparing surgery suitable for deeply infiltrating endometriosis? Eur J Obstet Gynecol Reprod Biol. 2014;175:87-91.

59. Morotti M, Sozzi F, Remorgida V, Venturini PL, Ferrero S. Dienogest in women with persistent endometriosis-related pelvic pain during norethisterone acetate treatment. Eur J Obstet Gynecol Reprod Biol. 2014;183:188-92.

60. Di Donato N, Montanari G, Benfenati A, Monti G, Leonardi D, Bertoldo V, Facchini C, Raimondo D, Villa G, Seracchioli R. Sexual function in women undergoing surgery for deep infiltrating endometriosis: a comparison with healthy women. J Fam Plann Reprod Health Care. 2015;41(4):278-83.

61. Morelli L, Perutelli A, Palmeri M, Guadagni S, Mariniello MD, Di Franco G, et al. Robot-assisted surgery for the radical treatment of deep infiltrating endometriosis with colorectal involvement: short- and mid-term surgical and functional outcomes. Int $\mathbf{J}$ Colorectal Dis. 2016;31:643-52.

62. Caruso S, Iraci M, Cianci S, Casella E, Fava V, Cianci A. Quality of life and sexual function of women affected by endometriosis-associated pelvic pain when treated with dienogest. J Endocrinol Invest. 2015;38:1211-8.

63. Fritzer N, Tammaa A, Haas D, Oppelt P, Renner S, Hornung D, et al. When sex is not on fire: a prospective multicentre study evaluating the short-term effects of radical resection of endometriosis on quality of sex life and dyspareunia. Eur J Obstet Gynecol Reprod Biol. 2016;197:36-40.

64. Meuleman C, D'Hoore A, Van Cleynenbreugel B, Beks N, D'Hooghe T. Outcome after multidisciplinary $\mathrm{CO} 2$ laser laparoscopic excision of deep infiltrating colorectal endometriosis. Reprod Biomed Online. 2009;18:282-9.

65. Meuleman C, Tomassetti C, D'Hoore A, Buyens A, Van Cleynenbreugel B, Fieuws S, et al. Clinical outcome after $\mathrm{CO}_{2}$ laser laparoscopic radical excision of endometriosis with colorectal wall invasion combined with laparoscopic segmental bowel resection and reanastomosis. Hum Reprod. 2011;26:2336-43.

66. Vercellini P, De Giorgi O, Mosconi P, Stellato G, Vicentini S, Crosignani PG.

Cyproterone acetate versus a continuous monophasic oral contraceptive in the treatment of

This article is protected by copyright. All rights reserved. 
recurrent pelvic pain after conservative surgery for symptomatic endometriosis. Fertil Steril. 2002;77:52-61.

67. Guzick D, Huang L, Broadman B, Nealon M, Hornstein M. Randomised trial of leuprolide versus continuous oral contraceptives in the treatment of endometriosis-associated pelvic pain. Fertil Steril. 2011;95:1568-73.

68. Vercellini P, Frattaruolo MP, Somigliana E, Jones GL, Consonni D, Alberico D, et al. Surgical versus low-dose progestin treatment for endometriosis-associated severe deep dyspareunia II: effect on sexual functioning, psychological status and health-related quality of life. Hum Reprod. 2013;28:1221-30.

69. Vercellini P, Bracco B, Mosconi P, Roberto A, Alberico D, Dhouha D, et al. Norethindrone acetate or dienogest for the treatment of symptomatic endometriosis: a before and after study. Fertil Steril. 2016;105:734-743.e3.

70. Vercellini P, Barbara G, Somigliana E, Bianchi S, Abbiati A, Fedele L. Comparison of contraceptive ring and patch for the treatment of symptomatic endometriosis. Fertil Steril. 2010;93:2150-61.

71. Hefler LA, Grimm C, Van Trotsemburg M, Nagele F. Role of the vaginally administered aromatase inhibitor anastrazole in women with rectovaginal endometriosis: a pilot study. Fertil Steril. 2005;84:1033-1036.

72. Razzi S, Luisi S, Calonaci F, Altomare A, Bocchi C, Petraglia F. Efficacy of vaginal danazol treatment in women with recurrent deeply infiltrating endometriosis. Fertil Steril. 2007;88:789-794.

73. Remorgida V, Abbamonte HL, Ragni N, Fulcheri N, Ferrero S. Letrozole and norethisterone in rectovaginal endometriosis. Fertil Steril. 2007;88:724-726.

74. Barbara G, Facchin F, Meschia M, Vercellini P. "The first cut is the deepest": a psychological, sexological and gynecological perspective on female genital cosmetic surgery. Acta Obstet Gynecol Scand. 2015;94:915-20.

75. Facchin F, Barbara G, Saita E, Mosconi P, Roberto A, Fedele L, et al. Impact of endometriosis on quality of life and mental health: pelvic pain makes the difference. $\mathbf{J}$ Psychosom Obstet Gynaecol. 2015;36:135-41.

This article is protected by copyright. All rights reserved. 


\section{Legends}

Figure 1. Study selection flow chart.

Table 1. Characteristics of studies included in systematic review of evaluation of sexual function after treatments for endometriosis.

Table 2. Interventions and main results of individual studies included in systematic review of evaluation of sexual function after treatments for endometriosis.

This article is protected by copyright. All rights reserved. 
Table 1. Characteristics of studies included in systematic review of evaluation of sexual function after treatments for endometriosis.

\begin{tabular}{|c|c|c|c|c|c|c|c|}
\hline $\begin{array}{l}\text { Author, } \\
\text { year }\end{array}$ & Country & $\begin{array}{l}\text { Study aims } \\
\text { (only regarding } \\
\text { sexual function) }\end{array}$ & $\begin{array}{l}\text { Study } \\
\text { design }\end{array}$ & Sample & Type of endometriosis & $\begin{array}{l}\text { Sexual } \\
\text { functioning } \\
\text { measures }\end{array}$ & $\begin{array}{l}\text { Time to } \\
\text { follow- } \\
\text { up } \\
\text { (months) }\end{array}$ \\
\hline $\begin{array}{l}\text { Vercellini } e t \\
\text { al., } 2002 \text { (66) }\end{array}$ & Italy & $\begin{array}{l}\text { To evaluate the degree of } \\
\text { satisfaction with medical } \\
\text { therapy }\end{array}$ & RCT & $\begin{array}{l}90 \text { women with } \\
\text { endometriosis }\end{array}$ & Women with rAFS stage I-IV & SRS Scale & 6 \\
\hline
\end{tabular}

This article is protected by copyright. All rights reserved. 


\begin{tabular}{|c|c|c|c|c|c|c|c|}
\hline $\begin{array}{l}\text { Author, } \\
\text { year }\end{array}$ & Country & $\begin{array}{l}\text { Study aims } \\
\text { (only regarding } \\
\text { sexual function) }\end{array}$ & $\begin{array}{l}\text { Study } \\
\text { design }\end{array}$ & Sample & Type of endometriosis & $\begin{array}{l}\text { Sexual } \\
\text { functioning } \\
\text { measures }\end{array}$ & $\begin{array}{l}\text { Time to } \\
\text { follow- } \\
\text { up } \\
\text { (months) }\end{array}$ \\
\hline $\begin{array}{l}\text { Ferrero et al., } \\
2007(52)\end{array}$ & Italy & $\begin{array}{l}\text { To evaluate the quality of } \\
\text { sex life and deep } \\
\text { dyspareunia after } \\
\text { laparoscopic full excision of } \\
\text { endometriosis combined } \\
\text { with postoperative } \\
\text { triptorelin treatment for } 6 \\
\text { monthts }\end{array}$ & $\begin{array}{l}\text { Observational } \\
\text { cohort study }\end{array}$ & $\begin{array}{l}98 \text { women with } \\
\text { endometriosis and } \\
64 \text { women with } \\
\text { inclusion of the } \\
\text { uterosacral } \\
\text { ligaments }\end{array}$ & Not specified & $\begin{array}{l}\text { Sexual Satisfaction } \\
\text { Subscale of the } \\
\text { DSFI; GSSI }\end{array}$ & 12 \\
\hline $\begin{array}{l}\text { Meulemann } e t \\
\text { al., } 2009 \text { (43) }\end{array}$ & Belgium & $\begin{array}{l}\text { To evaluate sexual } \\
\text { outcomes after } \mathrm{CO} 2 \\
\text { laparoscopic excision of } \\
\text { colorectal endometriosis }\end{array}$ & $\begin{array}{l}\text { Retrospective } \\
\text { cohort study }\end{array}$ & $\begin{array}{l}56 \text { women with } \\
\text { endometriosis }\end{array}$ & $\begin{array}{l}\text { Deep infiltrating colorectal } \\
\text { endometriosis } \\
95 \% \text { of women with rAFS stage } \\
\text { IV }\end{array}$ & $\begin{array}{l}\text { Sexual Activity } \\
\text { Questionnaire }\end{array}$ & $\begin{array}{l}29 \text { (median } \\
\text { follow-up } \\
\text { period) }\end{array}$ \\
\hline $\begin{array}{l}\text { Guzick et al., } \\
2011 \text { (67) }\end{array}$ & U.S.A & $\begin{array}{l}\text { To evaluate sexual } \\
\text { satisfaction in patients } \\
\text { underwent leuprolide versus } \\
\text { OC treatment for } \\
\text { endometriosis associated } \\
\text { pain }\end{array}$ & RCT & $\begin{array}{l}47 \text { women with } \\
\text { endometriosis }\end{array}$ & Not specified & $\begin{array}{l}\text { Index of Sexual } \\
\text { Satisfaction (ISS) }\end{array}$ & 12 \\
\hline
\end{tabular}

This article is protected by copyright. All rights reserved. 


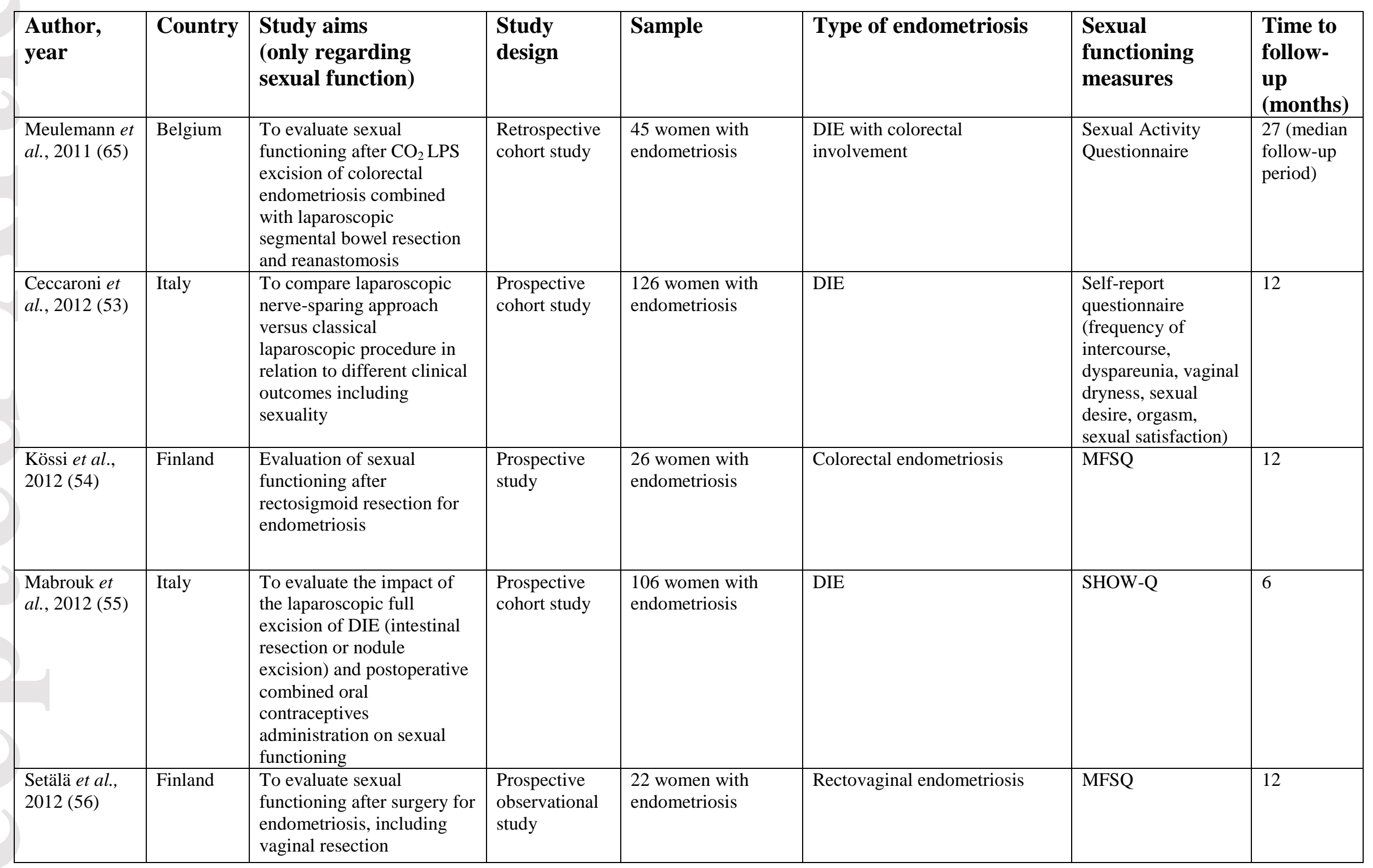

This article is protected by copyright. All rights reserved. 


\begin{tabular}{|c|c|c|c|c|c|c|c|}
\hline $\begin{array}{l}\text { Author, } \\
\text { year }\end{array}$ & Country & $\begin{array}{l}\text { Study aims } \\
\text { (only regarding } \\
\text { sexual function) }\end{array}$ & $\begin{array}{l}\text { Study } \\
\text { design }\end{array}$ & Sample & Type of endometriosis & $\begin{array}{l}\text { Sexual } \\
\text { functioning } \\
\text { measures }\end{array}$ & $\begin{array}{l}\text { Time to } \\
\text { follow- } \\
\text { up } \\
\text { (months) }\end{array}$ \\
\hline
\end{tabular}

\begin{tabular}{|c|c|c|c|c|c|c|c|}
\hline $\begin{array}{l}\text { Che at al., } \\
2014 \text { (58) }\end{array}$ & China & $\begin{array}{l}\text { To investigate the efficacy } \\
\text { of nerve-sparing surgery for } \\
\text { DIE on sexual functioning }\end{array}$ & $\begin{array}{l}\text { Prospective } \\
\text { study }\end{array}$ & $\begin{array}{l}108 \text { women with } \\
\text { endometriosis }\end{array}$ & DIE & FSFI & 24 \\
\hline $\begin{array}{l}\text { Morotti et al., } \\
2014 \text { (59) }\end{array}$ & Italy & $\begin{array}{l}\text { To evaluated changes in } \\
\text { sexual functioning at } 6- \\
\text { months dienogest treatment } \\
\text { in women who were } \\
\text { unsatisfied after } 6 \text {-months } \\
\text { of norethisterone acetate } \\
\text { therapy. }\end{array}$ & $\begin{array}{l}\text { Prospective } \\
\text { study }\end{array}$ & $\begin{array}{l}25 \text { women with } \\
\text { endometriosis }\end{array}$ & Rectovaginal endometriosis & FSFI & 6 \\
\hline $\begin{array}{l}\text { Caruso et al., } \\
2015(62)\end{array}$ & Italy & $\begin{array}{l}\text { To evaluate sexual } \\
\text { functioning and quality of } \\
\text { life in women with } \\
\text { symptomatic endometriosis }\end{array}$ & $\begin{array}{l}\text { Prospective } \\
\text { study }\end{array}$ & $\begin{array}{l}54 \text { women with } \\
\text { endometriosis and } \\
48 \text { women with } \\
\text { endometriosis who }\end{array}$ & Symptomatic endometriosis & FSFI, FSDS & 6 \\
\hline
\end{tabular}

This article is protected by copyright. All rights reserved. 


\begin{tabular}{|c|c|c|c|c|c|c|c|}
\hline & & and treated with dienogest & & $\begin{array}{l}\text { refused to take use } \\
\text { of dienogest }\end{array}$ & & & \\
\hline $\begin{array}{l}\text { Morelli et al., } \\
2016(61)\end{array}$ & Italy & $\begin{array}{l}\text { To evaluate sexual } \\
\text { functioning after robot- } \\
\text { assisted surgery for radical } \\
\text { treatment of DIE with } \\
\text { colorectal involvement }\end{array}$ & $\begin{array}{l}\text { Prospective } \\
\text { study }\end{array}$ & $\begin{array}{l}10 \text { women with } \\
\text { endometriosis }\end{array}$ & $\begin{array}{l}\text { DIE with recto-sigmoid colon } \\
\text { involvement }\end{array}$ & FSFI & 12 \\
\hline $\begin{array}{l}\text { Vercellini et } \\
\text { al., } 2016 \text { (69) }\end{array}$ & Italy & $\begin{array}{l}\text { To evaluate sexual } \\
\text { functioning after six months } \\
\text { of dienogest therapy versus } \\
\text { sexual functioning observed } \\
\text { during previous } \\
\text { noretisterone acetate } \\
\text { therapy }\end{array}$ & $\begin{array}{l}\text { Before and } \\
\text { after study }\end{array}$ & $\begin{array}{l}90 \text { women with } \\
\text { endometriosis }\end{array}$ & Symptomatic endometriosis & FSFI & 6 \\
\hline $\begin{array}{l}\text { Fritzer } \text { et al., } \\
2016(63)\end{array}$ & $\begin{array}{l}\text { Austria } \\
\text { and } \\
\text { Germany }\end{array}$ & $\begin{array}{l}\text { To evaluate the effect of } \\
\text { LPS radical resection of } \\
\text { endometriosis on quality of } \\
\text { sex life and dyspareunia }\end{array}$ & $\begin{array}{l}\text { Prospective } \\
\text { study }\end{array}$ & $\begin{array}{l}96 \text { women with } \\
\text { endometriosis }\end{array}$ & $\begin{array}{l}\text { Patients with histological } \\
\text { proven endometriosis and } \\
\text { dyspareunia lasting for at least } 6 \\
\text { months }\end{array}$ & FSFI, FSDS & 12 \\
\hline
\end{tabular}

Abbreviations: rAFS, revised American Fertility Society; DIE, deep infiltrating endometriosis; RCT, randomized controlled trial; SRS Scale, revised Sabbatsberg Sexual Self-Rating Scale; GSSI, Global Sexual Satisfaction Index; MFSQ, McCoy Female Sexuality Questionnaire; SHOW-Q, Sexual health Outcomes in Women Questionnaire; FSDS, Female Sexual Distress Scale; SSFS, Short Sexual Functioning Scale; FSFI, Female Sexual Function Index.

This article is protected by copyright. All rights reserved. 
Table 2. Interventions and main results of individual studies included in systematic review of evaluation of sexual function after treatments for endometriosis.

\begin{tabular}{|c|c|c|c|}
\hline Author, year & $\begin{array}{l}\text { Type of surgical } \\
\text { intervention }\end{array}$ & $\begin{array}{l}\text { Type of pharmacological } \\
\text { intervention }\end{array}$ & Results (Only sexual outcomes) \\
\hline Garry et al., 2000 (48) & $\begin{array}{l}\text { Radical laparoscopic } \\
\text { excision of all detected } \\
\text { endometriosis }\end{array}$ & /I & $\begin{array}{l}\text { Four months after surgery all domains of the questionnaire (habit,pleasure, and discomfort } \\
\text { with sex) significantly improved. }\end{array}$ \\
\hline Vercellini et al., 2002 (66) & // & $\begin{array}{l}\text { Low-dose cyproterone } \\
\text { acetate versus continuous } \\
\text { monophasic oral } \\
\text { contraceptive }\end{array}$ & $\begin{array}{l}\text { A significant improvement in sexual function was observed in both the cyproterone acetate } \\
\text { arm and the oral contraceptive arm; there were no significant differences between the two } \\
\text { groups. }\end{array}$ \\
\hline Abbott et al., 2003 (49) & $\begin{array}{l}\text { Laparoscopic excision } \\
\text { of endometriosis }\end{array}$ & /I & $\begin{array}{l}\text { There is a significant improvement in pleasure and habit, and a decrease in discomfort with } \\
\text { intercourse that is maintained up to } 5 \text { years.. }\end{array}$ \\
\hline Lyons et al, 2006 (50) & $\begin{array}{l}\text { Fertility-paring } \\
\text { laparoscopic surgery } \\
\text { with bowel resection }\end{array}$ & $/ /$ & $\begin{array}{l}\text { Sexual outcomes improved } 12 \text { months after surgery, although measurements did not reach } \\
\text { statistical significance }\end{array}$ \\
\hline Ferrero et al., 2007 (51) & $\begin{array}{l}\text { Complete laparoscopic } \\
\text { excision of all visible } \\
\text { endometriotic lesions }\end{array}$ & /I & $\begin{array}{l}12 \text { months after surgery patients with endometriosis of the uterosacral ligaments reported } \\
\text { increased variety in sex life, increased frequency of intercourse, more satisfying orgasms and } \\
\text { being more relaxed and fulfilled after sex. Similar improvements were observed among } \\
\text { women with endometriosis but no involvement of uterosacral ligaments; however for some } \\
\text { variables statistical significance was not reached. }\end{array}$ \\
\hline Ferrero et al., 2007 (52) & $\begin{array}{l}\text { Complete laparoscopic } \\
\text { excision of } \\
\text { endometriosis }\end{array}$ & $\begin{array}{l}\text { Postoperative triptorelin } \\
\text { treatment for } 6 \text { monthts }\end{array}$ & $\begin{array}{l}12 \text { months after surgery, } 45.9 \% \text { of patients had no deep dyspareunia, and } 34.7 \% \text { reported a } \\
\text { decrease in deep dyspareunia intensity. } 62.2 \% \text { of women reported an increase in the frequency } \\
\text { of sexual intercourse. Improvements in achieving orgasm and global sexual satisfaction were } \\
\text { reported. }\end{array}$ \\
\hline Meulemann et al.,2009 & Radical laser $\mathrm{CO}_{2}$ & // & Sexual function improved significantly following surgery with respect to pleasure, discomfort \\
\hline
\end{tabular}

This article is protected by copyright. All rights reserved. 


\begin{tabular}{|c|c|c|c|}
\hline Author, year & $\begin{array}{l}\text { Type of surgical } \\
\text { intervention }\end{array}$ & $\begin{array}{l}\text { Type of pharmacological } \\
\text { intervention }\end{array}$ & Results (Only sexual outcomes) \\
\hline$(64)$ & $\begin{array}{l}\text { laparoscopic excision } \\
\text { of deep infiltrating } \\
\text { colorectal } \\
\text { endometriosis, with } \\
\text { active involvement of a } \\
\text { colorectal surgeon } \\
\text { and/or urologist }\end{array}$ & & and frequency of sexual intercourse. \\
\hline Guzick et al., 2011 (67) & // & $\begin{array}{l}12 \text { months of either depot } \\
\text { leuprolide, } 11.25 \mathrm{mg} \text { every } \\
12 \text { weeks with hormonal } \\
\text { add-back using } \\
\text { norethindrone acetate } 5 \mathrm{mg} \\
\text { orally daily, or a generic } \\
\text { monophasic oral } \\
\text { contraceptive daily }\end{array}$ & There were no significant differences between the two groups as regard to sexual satisfaction \\
\hline $\begin{array}{l}\text { Meuleman et al., } 2011 \\
(65)\end{array}$ & $\begin{array}{l}\text { Radical laser } \mathrm{CO}_{2} \\
\text { laparoscopic excision } \\
\text { of deep infiltrating } \\
\text { colorectal } \\
\text { endometriosis, } \\
\text { combined with } \\
\text { laparoscopic segmental } \\
\text { bowel resection and } \\
\text { reanastomosis }\end{array}$ & // & $\begin{array}{l}\text { The sexual activity questionnaire showed a significant improvement after surgery in sexual } \\
\text { pleasure, frequency of sexual activity and a significant reduction in discomfort during sexual } \\
\text { intercourse }\end{array}$ \\
\hline Ceccaroni et al.,2012 (53) & $\begin{array}{l}\text { Nerve-sparing radical } \\
\text { excision of pelvic } \\
\text { endometriosis with } \\
\text { segmental bowel } \\
\text { resection (group B) } \\
\text { versus laparoscopic } \\
\text { non nerve-sparing } \\
\text { excision of pelvic } \\
\text { endometriosis with } \\
\text { bowel resection (group } \\
\text { A) }\end{array}$ & // & $\begin{array}{l}\text { No difference were found between the two groups in frequency of sexual intercourses after } \\
\text { interventions and the rates of patients claiming dyspareunia, psychological distress and } \\
\text { vaginal dryness. Patients in group A claimed more frequent vaginal bleeding, lowered sexual } \\
\text { desire. Contrarily, a reduced sexual pleasure/frequency of orgasm was claimed by more } \\
\text { patients in group B. }\end{array}$ \\
\hline
\end{tabular}

This article is protected by copyright. All rights reserved. 


\begin{tabular}{|c|c|c|c|}
\hline Author, year & $\begin{array}{l}\text { Type of surgical } \\
\text { intervention }\end{array}$ & $\begin{array}{l}\text { Type of pharmacological } \\
\text { intervention }\end{array}$ & Results (Only sexual outcomes) \\
\hline Kössi et al., 2012 (54) & $\begin{array}{l}\text { Laparoscopic complete } \\
\text { excision of all pelvic } \\
\text { endometriotic lesions } \\
\text { and bowel resection for } \\
\text { colorectal } \\
\text { endometriosis }\end{array}$ & // & $\begin{array}{l}12 \text { months after surgery a significant increase in the sexual satisfaction subscale }(P=0.01) \text { was } \\
\text { observed. A statistically significant decrease was detected in "painful sexual intercourse". } \\
\text { Sexual problems and partner satisfaction scores had not changed significantly. }\end{array}$ \\
\hline Mabrouk et al.,2012 (55) & $\begin{array}{l}\text { Laparoscopic surgery } \\
\text { for deep endometriosis: } \\
\text { complete, nerve } \\
\text { sparing excision of } \\
\text { endometriotic lesions } \\
\text { (intestinal resection or } \\
\text { nodulectomy). }\end{array}$ & $\begin{array}{l}\text { Postoperative } \\
\text { administration of OC }\end{array}$ & $\begin{array}{l}\text { At } 6 \text { months follow-up sexual desire, satisfaction with sex and pelvic problem interference } \\
\text { with intercourse are significantly improved }(P<0.05) \text {. Laparoscopic management of DIE did } \\
\text { not change significantly the orgasm area of the sexual function }(P=0.7) \text { No difference in } \\
\text { sexual outcomes was observed between patients submitted to intestinal resection or nodule } \\
\text { excision. }\end{array}$ \\
\hline Setälä et al., 2012 (56) & $\begin{array}{l}\text { Complete excision of } \\
\text { endometriotic nodules } \\
\text { in the posterior fornix } \\
\text { of the vagina, including } \\
\text { vaginal resection, by a } \\
\text { laparoscopic or } \\
\text { combined } \\
\text { laparoscopic-vaginal } \\
\text { approach. }\end{array}$ & // & $\begin{array}{l}12 \text { months after surgery, the sexual satisfaction score was higher }(P=0.03) \text { and the sexual } \\
\text { problems score lower }(\mathrm{P}=0.04) \text { compared with baseline values. }\end{array}$ \\
\hline $\begin{array}{l}\text { Van den Broeck et al., } \\
2013 \text { (57) }\end{array}$ & $\begin{array}{l}\text { Laparoscopic radical } \\
\text { surgery for } \\
\text { endometriosis, with or } \\
\text { without bowel } \\
\text { resection }\end{array}$ & $/ /$ & $\begin{array}{l}\text { Overall women in the bowel resection group had better outcomes in the SSFS arousal domain } \\
\text { For sexual desire, orgasm problems and pain during intercourse no significant differences } \\
\text { between the two groups were found }(P<0.05) \text {. }\end{array}$ \\
\hline Vercellini et al., 2013 (68) & $\begin{array}{l}51 \text { patients in surgery } \\
\text { group: attempt to } \\
\text { remove all } \\
\text { endometriosis lesions. } \\
\text { Two patient with } \\
\text { rectovaginal lesions } \\
\text { underwent colorectal } \\
\text { resection }\end{array}$ & $\begin{array}{l}103 \text { patient in progestin } \\
\text { group: } \\
\text { Norethisterone acetate } 2.5 \\
\text { mg per day }\end{array}$ & $\begin{array}{l}\text { Global sexual function improved immediately in the surgery group, but worsened with time, } \\
\text { whereas sexual function improved more gradually, but progressive, in the progestin therapy } \\
\text { group. No significant differences were observed between the two study group at } 12 \text { months } \\
\text { follow-up. A tendency was observed towards a slightly better sexual function after surgery at } \\
\text { the end of the study period. }\end{array}$ \\
\hline
\end{tabular}

This article is protected by copyright. All rights reserved. 


\begin{tabular}{|c|c|c|c|}
\hline Author, year & $\begin{array}{l}\text { Type of surgical } \\
\text { intervention }\end{array}$ & $\begin{array}{l}\text { Type of pharmacological } \\
\text { intervention }\end{array}$ & Results (Only sexual outcomes) \\
\hline Che at al., 2014 (58) & $\begin{array}{l}\text { A total of } 108 \text { women } \\
\text { underwent } \\
\text { conventional } \\
\text { laparoscopic or } \\
\text { laparotomic surgery } \\
\text { (n=63) or nerve- } \\
\text { sparing surgery }(\mathrm{n}=45) \\
\text { for the treatment of } \\
\text { DIE }\end{array}$ & /I & $\begin{array}{l}\text { The total postoperative FSFI score } 24 \text { months after surgery increased significantly in both } \\
\text { groups, with no between-group difference. When analyzed separately for each FSFI domains, } \\
\text { both groups showed similar results for desire, arousal, and orgasm and had an elevated score } \\
\text { immediately after surgery, which almost remained unchanged over time. Differently, pain } \\
\text { score significantly increase after surgery and dropped over time. For satisfaction FSFI } \\
\text { domain, the results showed no significant difference at the 24-month follow-up compared } \\
\text { with the pre-operative assessment. However, the total post-operative FSFI score and the } 6 \\
\text { subdomain scores of the questionnaire were below the cut-off of dysfunction before and after } \\
\text { surgery. }\end{array}$ \\
\hline Morotti et al., 2014 (59) & $/ /$ & $\begin{array}{l}\text { Treatment with dienogest in } \\
\text { patients who were } \\
\text { unsatisfied with previous } 6 \\
\text { months norestisterone } \\
\text { acetate treatment }\end{array}$ & $\begin{array}{l}\text { Women after } 6 \text { months of dienogest treatment showed increased FSFI values compared to } \\
\text { women at the end of } 6 \text { months of noretisterone acetate treatment. Regarding each domain of } \\
\text { the FSFI questionnaire, a statistical increase was found on lubrication and pain scores }\end{array}$ \\
\hline $\begin{array}{l}\text { Di Donato et al., } 2015 \\
(60)\end{array}$ & $\begin{array}{l}\text { Complete laparoscopic } \\
\text { excision of all visible } \\
\text { endometriotic lesions }\end{array}$ & $/ /$ & $\begin{array}{l}\text { A significant improvement was found between pre- and post- laparoscopic surgery in the } \\
\text { desire, satisfaction, and pelvic problem interference with sex scales of the sexual } \\
\text { questionnaire. At } 6 \text { months follow-up the distribution of the SHOW-Q scores was comparable } \\
\text { to healthy women's scores, apart for the orgasm score. }\end{array}$ \\
\hline Caruso et al., 2015 (62) & /I & 6-months Dienogest therapy & $\begin{array}{l}\text { All aspects of the FSFI and FSDS questionnaire significantly improved after } 6 \text { months od } 2 \\
\mathrm{mg} / \text { daily dienogest therapy, as compared to the control group }\end{array}$ \\
\hline Morelli et al., 2016 (61) & $\begin{array}{l}\text { Robot-assisted surgery } \\
\text { for the radical } \\
\text { treatment of DIE with } \\
\text { colorectal involvement }\end{array}$ & $\begin{array}{l}\text { Post-operative OC in all } \\
\text { cases except for women who } \\
\text { were trying to conceive }\end{array}$ & $\begin{array}{l}\text { All aspects of the FSFI questionnaire worsened significantly } 1 \text { month after surgery, but } \\
\text { showed a subsequent progressive increase and } 12 \text { months post surgery the scores were } \\
\text { comparable to those assessed pre-operatively. Dyspareunia was significantly improved } 12 \\
\text { months after surgery with respect to the baseline assessment. }\end{array}$ \\
\hline Vercellini et al., 2016 (69) & /I & 6-months Dienogest therapy & $\begin{array}{l}\text { A statistically significant increase in total FSFI score was observed in women treated with } \\
\text { dienogest, with no statistically differences compared with women treated with noretisterone } \\
\text { acetate. The increase in sexual function was homogenous on the six different subdomain of } \\
\text { the FSFI. Although, the } 6 \text { month total FSFI score remained below the threshold for sexual } \\
\text { dysfunction }\end{array}$ \\
\hline Fritzer et al., 2016 (63) & $\begin{array}{l}\text { Laparoscopical radical } \\
\text { resection of } \\
\text { endometriosis }\end{array}$ & // & $\begin{array}{l}\text { Pain scores as well as feelings of guilt toward the partner, being afraid of pain and feeling of } \\
\text { being a burden for the relationship significantly decreased after surgery. }\end{array}$ \\
\hline
\end{tabular}

Abbreviations: OC, oral contraceptives; FSFI: Female Sexual Function Index; DIE: deep infiltrating endometriosis; SSFS: Short sexual functioning scale; FSDS: Female Sexual Distress Scale; SHOW-Q: Sexual health Outcomes in Women Questionnaire.

This article is protected by copyright. All rights reserved. 
Figure 1. Study selection flow chart.

Total number of records identified

through database searching

$$
(n=615)
$$

\begin{tabular}{|c|c|}
\hline & \multirow[t]{2}{*}{$\begin{array}{l}\text { Records excluded by title and/or by } \\
\text { abstract and duplicates removed } \\
\qquad(n=555)\end{array}$} \\
\hline \multirow[t]{2}{*}{$\begin{array}{l}\text { Full-text articles assessed for } \\
\text { eligibility according to inclusion and } \\
\text { exclusion criteria } \\
\qquad(\mathrm{n}=60)\end{array}$} & \\
\hline & $\begin{array}{l}\text { Full-text articles excluded }(n=38) \text { : } \\
\text { - } 3 \text { were not written in English; } \\
\text { - } 11 \text { were review articles or } \\
\text { commentaries; } \\
\text { - } 2 \text { were qualitative studies; } \\
\text { - } 14 \text { considered dyspareunia as } \\
\text { the only sexual outcome and } \\
\text { measures did not involve } \\
\text { comprehensive sexual } \\
\text { questionnaires or no specific } \\
\text { information from the } \\
\text { questionnaires used was } \\
\text { reported. }\end{array}$ \\
\hline $\begin{array}{l}\text { Studies included in the current review } \\
\qquad(n=22)\end{array}$ & $\begin{array}{l}\text { - } 8 \text { were studies on the impact } \\
\text { of having endometriosis on } \\
\text { sexual functioning, without } \\
\text { considering the effect of any } \\
\text { medical intervention }\end{array}$ \\
\hline
\end{tabular}

This article is protected by copyright. All rights reserved. 